\title{
A HISTORY OF SPANISH PAINTING
}

\author{
VOLUME V
}


LONDON : HUMPHREY MILFORD

OXFORD UNIVERSITY PRESS 


\section{A HISTORY OF SPANISH PAINTING}

BY

CHANDLER RATHFON POST

HARVARD UNIVERSITY

VOLUME V

THE HISPANO-FLEMISH STYLE IN ANDALUSIA

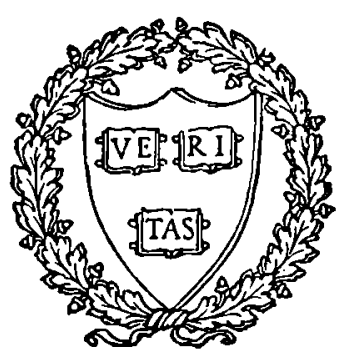

CAMBRIDGE, MASSACHUSETTS

HARVARD UNIVERSITY PRESS

1934 
COPYRIGHT, 1934

BY THE PRESIDENT AND FELLOWS OF HARVARD COLLEGE

PRINTED AT THE HARVARD UNIVERSITY PRESS

CAMBRIDGE, MASS., U.S.A. 